\title{
ROS-induced oxidative stress in plant cryopreservation: occurrence and alleviation
}

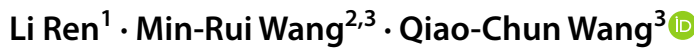

Received: 2 August 2021 / Accepted: 8 November 2021 / Published online: 20 November 2021

(c) The Author(s) 2021

\begin{abstract}
Main conclusion Reactive oxygen species (ROS)-induced oxidative stress results in low success or even total failure of cryopreservation. Better understanding of how the plant establishes resistance/tolerance to ROS-induced oxidative stress facilitates developments of robust cryopreservation procedures.
\end{abstract}

\begin{abstract}
Cryopreservation provides a safe and efficient strategy for long-term preservation of plant genetic resources. ROSinduced oxidative stress caused damage to cells and reduced the ability of the plant to survive following cryopreservation, eventually resulting in low success or even total failure. This paper provides updated and comprehensive information obtained in the past decade, including the following: (1) ROS generations and adaptive responses of antioxidant systems during cryopreservation; (2) expressions of oxidative stress-associated genes and proteins during cryopreservation; (3) ROS-triggered programmed cell death (PCD) during cryopreservation; and (4) exogenous applications of enzymatic and non-enzymatic antioxidants in improving success of cryopreservation. Prospects for further studies are proposed. The goal of the present study was to facilitate better understanding of the mechanisms by which the plant establishes resistance/tolerance to oxidative stress during cryopreservation and promote further studies toward the developments of robust cryopreservation procedures and wider application of plant cryobiotechnology.
\end{abstract}

Keywords Antioxidants · Cryopreservation · Gene expression · Oxidative stress · Programmed cell death · Reactive oxygen species

\section{Introduction}

Plant cryopreservation refers to storage of plant cells, tissue and organs in liquid nitrogen $\left(\mathrm{LN},-196^{\circ} \mathrm{C}\right)$ or liquid nitrogen vapor (LNV, approx. -165 to $\left.-190^{\circ} \mathrm{C}\right)(\mathrm{Kacz}-$ marczyk et al. 2012; Wang et al. 2021a). Cryopreservation

Communicated by Gerhard Leubner.

Qiao-Chun Wang

qiaochunwang@nwsuaf.edu.cn

1 Institute for Agri-Food Standards and Testing Technology, Shanghai Academy of Agricultural Sciences, Shanghai 201403, People's Republic of China

2 State Key Laboratory of Crop Stress Biology for Arid Region, College of Life Science, Northwest A\&F University, Yangling 712100, Shaanxi, People's Republic of China

3 State Key Laboratory of Crop Stress Biology for Arid Region, College of Horticulture, Northwest A\&F University, Yangling 712100, Shaanxi, People's Republic of China is considered at present time an ideal means for long-term preservation of plant genetic resources (Kaczmarczyk et al. 2012; Bettoni et al. 2021; Wang et al. 2014, 2021a, b). Cryo-banks using shoot tips have been set up in several countries for economically important plant species (Kulus and Zalewska 2014; Wang et al. 2014; Vollmer et al. 2016; Jenderek and Reed 2017). Cryobiotechnology has also been extended to long-term preservation of transgenes in transgenic cells (Wang et al. 2012, 2014), production of pathogen-free plants (Wang and Valkonen 2009; Wang et al. 2014; Zhao et al. 2019) and long-term preservation of obligate pathogens such as viruses and viroids (Zhao et al. 2019). Studies have also advanced in the evaluation of the performance of cryo-derived plants when they were re-introduced from laboratories to their natural habitats (Salama et al. 2018; Bi et al. 2021). However, ROS-induced oxidative stress is recognized to be a major constraint for further developments of plant cryopreservation, particularly endangered, endemic and 
tropical species, which are still recalcitrant to cryopreservation (Kaczmarczyk et al. 2012; Reed 2014; Funnekotter et al. 2017; Normah et al. 2019; Streczynski et al. 2019; Coelho et al. 2020).

As signaling molecules, ROS supports cellular proliferation and physiological function, and therefore, maintenance of a basal level of ROS is essential for life (Mittler 2017). However, overproduction of ROS is highly reactive and toxic and causes damage to DNA and protein, as well as membrane oxidation (Gill and Tuteja 2010; Mittler 2017). Under normal circumstances, there is a balance between ROS production and clearance in plants. However, under stress conditions, excessive ROS are produced, resulting in oxidative stress (Gill and Tuteja 2010). Oxidative stress refers to a state of imbalance between oxidation and antioxidation, which is caused by excessive generations of ROS (Halliwell 2006; Mittler 2017). $\mathrm{O}_{2} \cdot-, \mathrm{H}_{2} \mathrm{O}_{2}$, and $\mathrm{OH} \cdot$ are the three major ROS and $\mathrm{H}_{2} \mathrm{O}_{2}$ is the main ROS component that causes membrane lipid peroxidation in plant cryopreservation (Chen et al. 2015; Ren et al. 2015; Zhang et al. 2015). Detailed information on generation of $\mathrm{O}_{2} \cdot-, \mathrm{H}_{2} \mathrm{O}_{2}$ and $\mathrm{OH}$. can be found in the articles of Mittler (2002) and Vranová et al. (2002).

In response to oxidative stress, plants develop antioxidant defense systems via enzymatic and non-enzymatic antioxidant reactions to maintain normal metabolisms and functions in the cell, thus protecting themselves against oxidative stress (Gill and Tuteja 2010). An antioxidant is defined as a molecule or compound that can delay, prevent, or remove damage caused by oxidative stress (Halliwell 2006). Plant antioxidants include two types: enzymatic and non-enzymatic, both of which can regulate ROS production (Halder et al. 2018). Enzymatic antioxidants mainly include superoxide dismutase (SOD), peroxidase (POD), catalase (CAT), ascorbate peroxidase (APX), monodehydroascorbate reductase (MDHAR), glutathione reductase (GR), glutathione peroxidase (GPX) and dehydroascorbate reductase (DHAR) (Gill and Tuteja 2010). Non-enzymatic antioxidants consist of many members, for example, glutathione (GSH), ascorbic acid (AsA), abscisic acid (ABA), tocopherol (VE) and melatonin (Gill and Tuteja 2010; Nawaz et al. 2016; Sah et al. 2016). Among these antioxidants, SOD functions in scavenging $\mathrm{O}_{2} \cdot-$ and lowering the possibility of $\mathrm{OH} \cdot$ production (Scandalios 1990). POD, CAT and APX play an essential protective role in scavenging $\mathrm{H}_{2} \mathrm{O}_{2}$ when coordinating with SOD (Chaitanya et al. 2002). Melatonin fortifies plants against abiotic and biotic stress, mainly by scavenging ROS and reactive nitrogen species (Nawaz et al. 2016). AsA is the most effective water-soluble antioxidant in plants, which can provide electrons to a large number of antioxidants (Gill and Tuteja 2010) and scavenge $\mathrm{O}_{2} \cdot-$ and $\mathrm{H}_{2} \mathrm{O}_{2}$ (Noctor and Foyer 1998; Smirnoff 2000). GSH helps to scavenge ROS via AsA-GSH cycle and a balance between
GSH and oxidized glutathione is important for maintaining the redox status of cells (Pastori et al. 2000; Gill and Tuteja 2010).

Plant cryopreservation requires several necessary steps such as the establishment of stock cultures, excision of explants, preculture, osmoprotection and cryoprotection, dehydration, freeze-thaw cycle, unloading and post-culture for recovery (Fig. 1A). All these steps induce ROS generation (Fig. 1B, C, E, F). ROS-induced oxidative stress reduces the ability of the explant to survive following cryopreservation, eventually resulting in poor recovery or even total failure (Benson and Bremner 2004; Kaczmarczyk et al. 2012; Reed 2014; Funnekotter et al. 2017; Normah et al. 2019; Streczynski et al. 2019; Coelho et al. 2020; Fig. 1B, C, F-H).

This review focuses on advances over the past decade in analyses of ROS generation and adaptive responses of the antioxidant system during cryopreservation procedures. ROS-induced programmed cell death (PCD), and expressions of oxidative stress-associated genes and proteins in cryopreservation are also presented. Finally, applications of enzymatic and non-enzymatic antioxidants to improvements of recovery of cryopreserved explants are presented in detail.

\section{ROS generation, programmed cell death (PCD) and adaptive responses of antioxidant system in plant cryopreservation}

\section{ROS generation}

In vitro tissue culture has become an integral part of the cryopreservation technology currently used for the establishment and maintenance of stock cultures, and the postculture process for the recovery of cryopreserved tissues (Funnekotter et al. 2017; Wang et al. 2021b; Fig. 1A). It is well documented that in vitro tissue culture imposes stressful conditions and induces the generations of ROS, thus resulting in ROS-induced oxidative stress (Kaczmarczyk et al. 2012; Funnekotter et al. 2017; Bednarek and Orłowska 2020; Wang et al. 2021b; Fig. 1B, F). Cold-hardening of the in vitro stock cultures was frequently used for improving plant cryopreservation (Kaczmarczyk et al. 2012; Funnekotter et al. 2017). Cold-hardening of the in vitro stock cultures was proven to induce expressions of antioxidant enzymes, such as SOD and catalase, increase antioxidant levels, and maintain membrane stability, eventually enhancing recovery of cryopreserved plants (Kaczmarczyk et al. 2012; Funnekotter et al. 2017).

It has been known for a long time that age of stock cultures from which explants were excised and used for cryopreservation considerably affected success of cryopreservation (Wang and Perl 2006). Using vitrification cryopreservation for different ages of Arabidopsis thaliana 


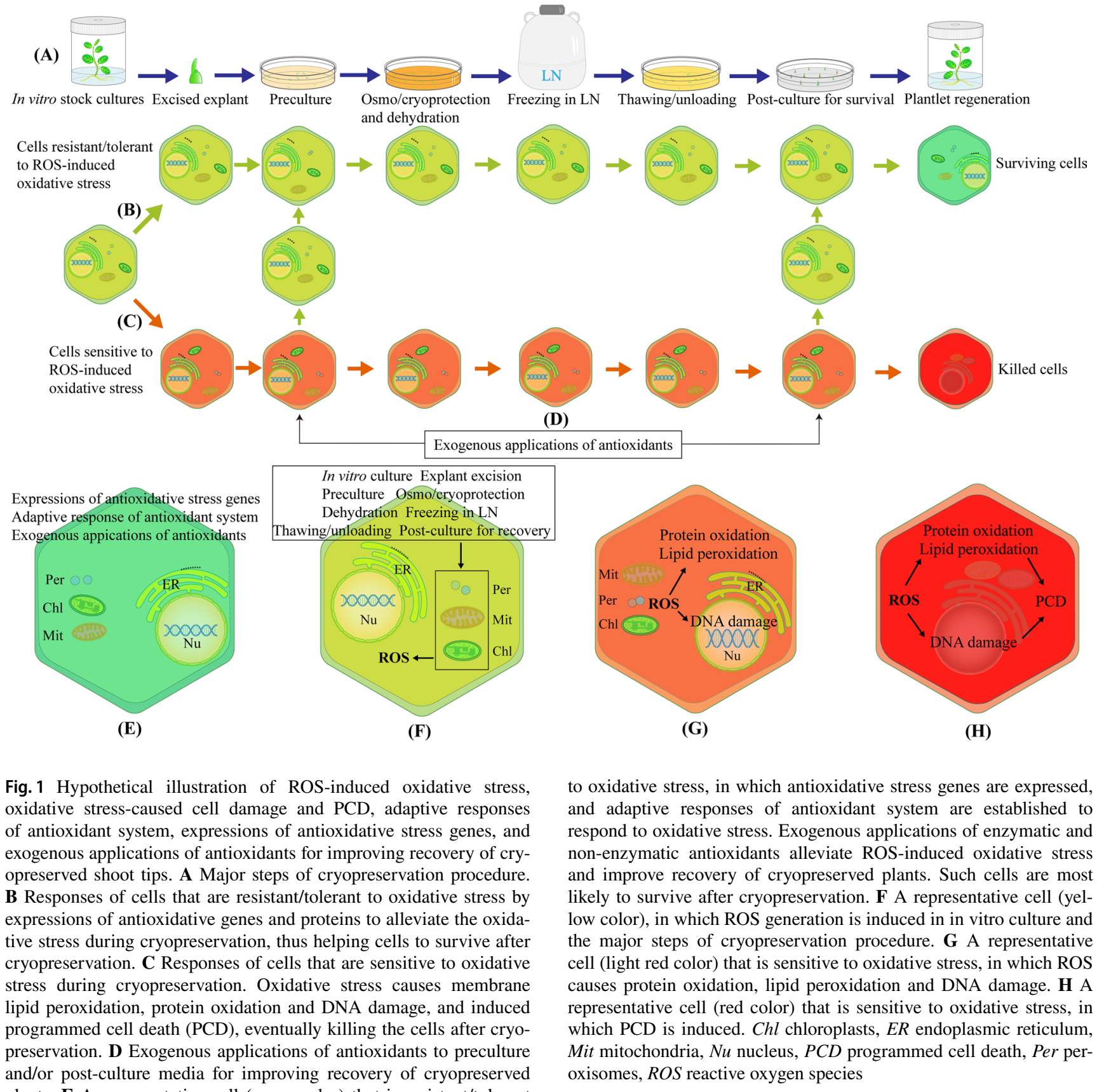

plants. $\mathbf{E}$ A representative cell (green color) that is resistant/tolerant

seedlings, Ren et al. (2013) found that survival of cryopreserved seedlings significantly decreased with an increase in age of stock seedlings: $97 \%$ and $0 \%$ for 48 -h and 72-h seedlings, respectively. MDA was much higher in the 72-h stock seedlings than in the 48 -h ones following osmoprotection and dehydration. There was a significant negative correlation between MDA content and survival levels following cryopreservation. A further study of the same group found that during the whole vitrification procedure, $\mathrm{O}_{2} \cdot-$ activities were much higher and $\mathrm{H}_{2} \mathrm{O}_{2}$ levels were much lower in the 48-h seedlings than in the 72-h ones. Chen et al. (2015) reported that although $\mathrm{OH} \cdot$ activities continuously increased during the whole cryopreservation procedure, the increased $\mathrm{OH} \cdot$ activities were much more pronounced in 72-h seedlings than in 48-h ones. These findings provide new insights on better understanding of the mechanism as to how the age of stock cultures influences plant cryopreservation.

Excision of the explant is a necessary step, particularly in cryopreservation of shoot tips and embryogenic tissues. Excision of the explant is a wounding process, which has been documented to induce accumulations of ROS (Savatin et al. 2014). Roach et al. (2008) reported that the excision 
of embryonic axes from the seeds of a recalcitrant sweet chestnut (Castanea sativa) induced an oxidative burst of $\mathrm{O}_{2} \cdot-$, resulting in the reduced viability of the axes following desiccation and subsequent freezing in LN. More examples that explant excision-mediated oxidative stress were responsible for the reduced recoveries of cryopreserved explants are listed in Table 1.

Using a vitrification cryo-plate (V cryo-plate) for cryopreservation of Paphiopedilum niveum somatic embryos, Soonthornkalump et al. (2020) found that the highest level of the total ROS was induced in the preculture step. MDA level started to significantly increase from the preculture and reached the highest level in the osmoprotection step. These results indicated that preculture step was a critical step for successful cryopreservation of Paphiopedilum niveum somatic embryos.

Working on dehydration cryopreservation of recalcitrant seeds of Ekebergia capensis, Bharuth and Naidoo (2020) found that the reduced survival levels were closely associated with the increased levels of $\mathrm{O}_{2} \cdot-$ and $\mathrm{H}_{2} \mathrm{O}_{2}$ in each step of explant excision, cryoprotection, dehydration and freezing in LN. In the study of vitrification cryopreservation for Oryza sativa zygotic embryos, Huang et al. (2018) found that the major steps significantly affected levels of $\mathrm{O}_{2} \cdot-$ and MDA, which were negatively correlated with survival of the embryos following cryopreservation. Analyzing ROS production in zygotic embryos of recalcitrant Haemanthus montanus seeds subjected to cryopreservation, Sershen et al. (2012) found that although dehydration and cryoprotection increased $\mathrm{O}_{2} \cdot-$ levels, freezing in LN induced the highest level of $\mathrm{O}_{2} \cdot-$, and was responsible for considerable or complete viability loss of the zygotic embryos following cryopreservation.

In vitrification cryopreservation of Arabidopsis seedlings, $\mathrm{H}_{2} \mathrm{O}_{2}$ and $\mathrm{OH} \cdot$ content continuously increased during the cryopreservation procedure and reached the highest level after rapid warming (Ren et al. 2015). Further analysis found that a large amount of ROS induced in the freeze-thaw cycle altered the redox state in the cell, caused membrane lipid peroxidation, and destroyed plant photosynthetic phosphorylation and oxidative phosphorylation systems (Ren et al. 2013, 2015). All these negative effects of excessive accumulations of ROS resulted in the reduced recovery of cryopreserved Arabidopsis seedlings.

It is worth noting that the production of ROS was found to increase the viability of pollen after cryopreservation in Lilium $\times$ siberia (Xu et al. 2014). In this study, ROS generation was analyzed by a flow cytometry with 2 ', 7'-dichlorodihydrofluorescein diacetate (DCFH-DA) fluorescent probe. The fluorescence levels at $488 \mathrm{~nm}$ (excitation) and $525 \mathrm{~nm}$ (emission) were expressed as mean green intensity fluorescence units for index of ROS level. ROS increased from 16 in the control to 26 and 50 in cryopreserved pollen by rapid cooling and vitrification, respectively. Pollen viability significantly increased from $47 \%$ in the control (fresh pollen) to $59 \%$ and $70 \%$ in cryopreserved pollen by rapid cooling and vitrification, respectively (Xu et al. 2014). These results indicate that ROS may have positive effects on cryopreservation, and the positive effects may depend on its concentration, plant species, types of explant and cryogenic procedures used.

ROS-induced oxidative stress and cell damage are illustrated in Fig. 1C, F and some examples of ROS generation and cell damage induced in plant cryogenic procedures are listed in Table 1.

\section{ROS-induced PCD}

PCD refers to an ordered and energy-required physiological process that is genetically programmed, eventually leading to the cell death (Reape and McCabe 2008). There are three main forms in PCD, including apoptosis, necrosis and autophagic cell death (Reape and McCabe 2008). It has been well documented that the generation and accumulation of ROS under oxidative stress induced PCD, and apoptosis and necrosis were considered the major forms of PCD in cryopreservation (Reape and McCabe 2008; Bissoyi et al. 2014).

Harding et al. (2009) were the first to propose that cryopreservation may induce PCD in plants. Since then, oxidative stress-mediated ROS has been proven to be involved in induction of PCD in plant cryopreservation. Working on Eucalyptus grandis axillary buds, Risenga et al. (2013) found that bud excision and drying induced high ROS levels, which reduced viability of the explant analyzed by caspase3-like protease activity. Caspases have been demonstrated to be responsible for the stress-triggered PCD processes (Reape and McCabe 2008). Therefore, Risenga et al. (2013) believed that dehydration-induced ROS generation triggered PCD. Wesley-Smith et al. (2015) found that exposure to LN resulted in autophagic degradation and ultimately autolysis, and formation of small intracellular ice crystals in cryopreserved embryonic axes of recalcitrant Acer saccharinum seeds. These results indicated that freezing stress induced PCD. In cryopreservation of Dendrobium PLBs by vitrification, Jiang et al. (2019) found that the preculture and freeze-thaw cycle induced expression of the autophagyrelated protein $8 \mathrm{C}$ gene (Atg $8 C$ ) and reticulon-like protein B8 gene (Rtnl B8). Caspase-3-like activity increased following the osmoprotection treatment and dehydration and reached the highest level following freeze-thaw cycle. Levels of $\mathrm{H}_{2} \mathrm{O}_{2}$ and $\mathrm{NO}$ started to increase in the preculture stage and reached the highest level in the osmoprotection treatment. These results provided experimental concrete evidence that ROS generations triggered PCD in cryopreservation (Jiang et al. 2019). 


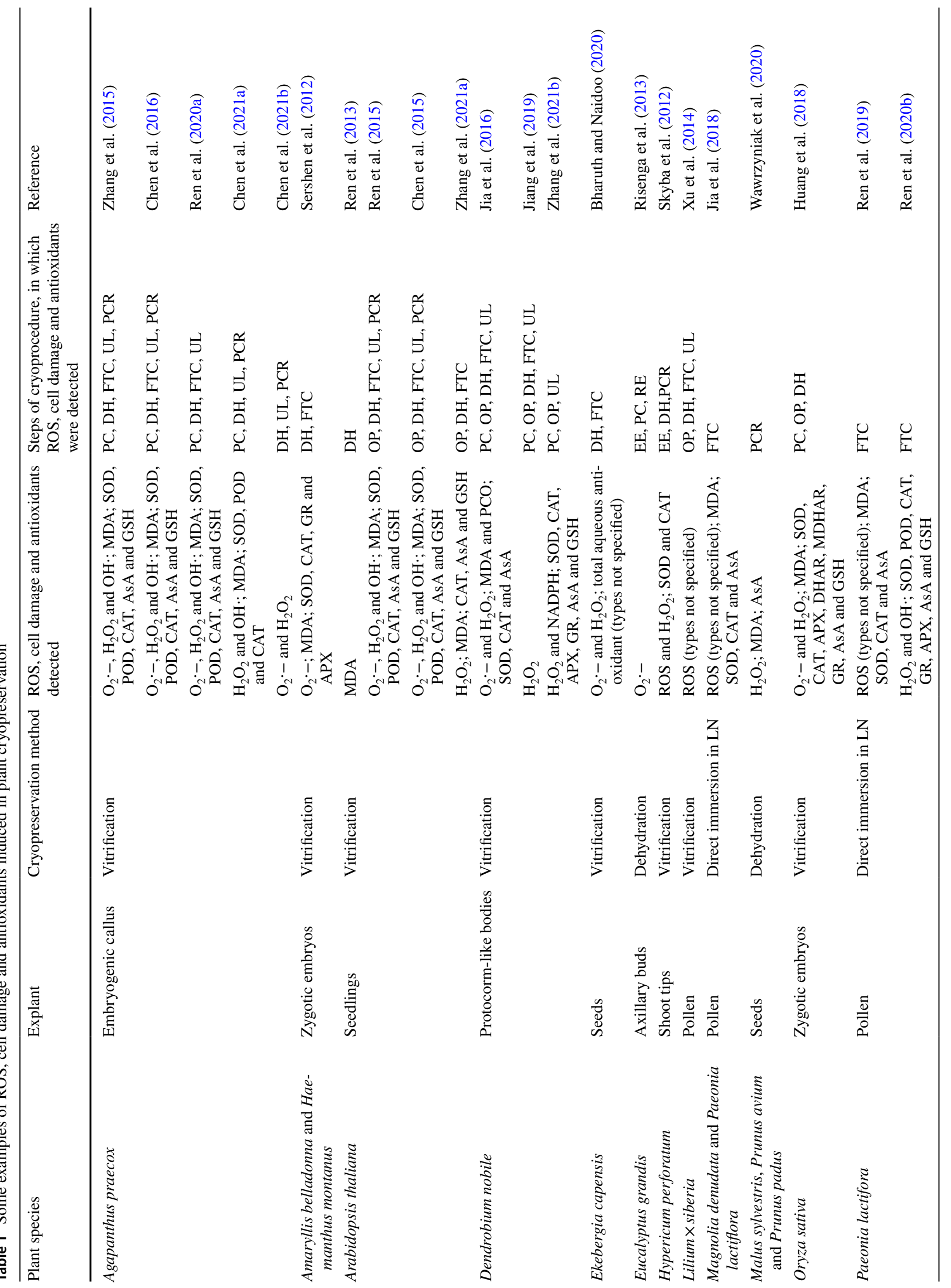




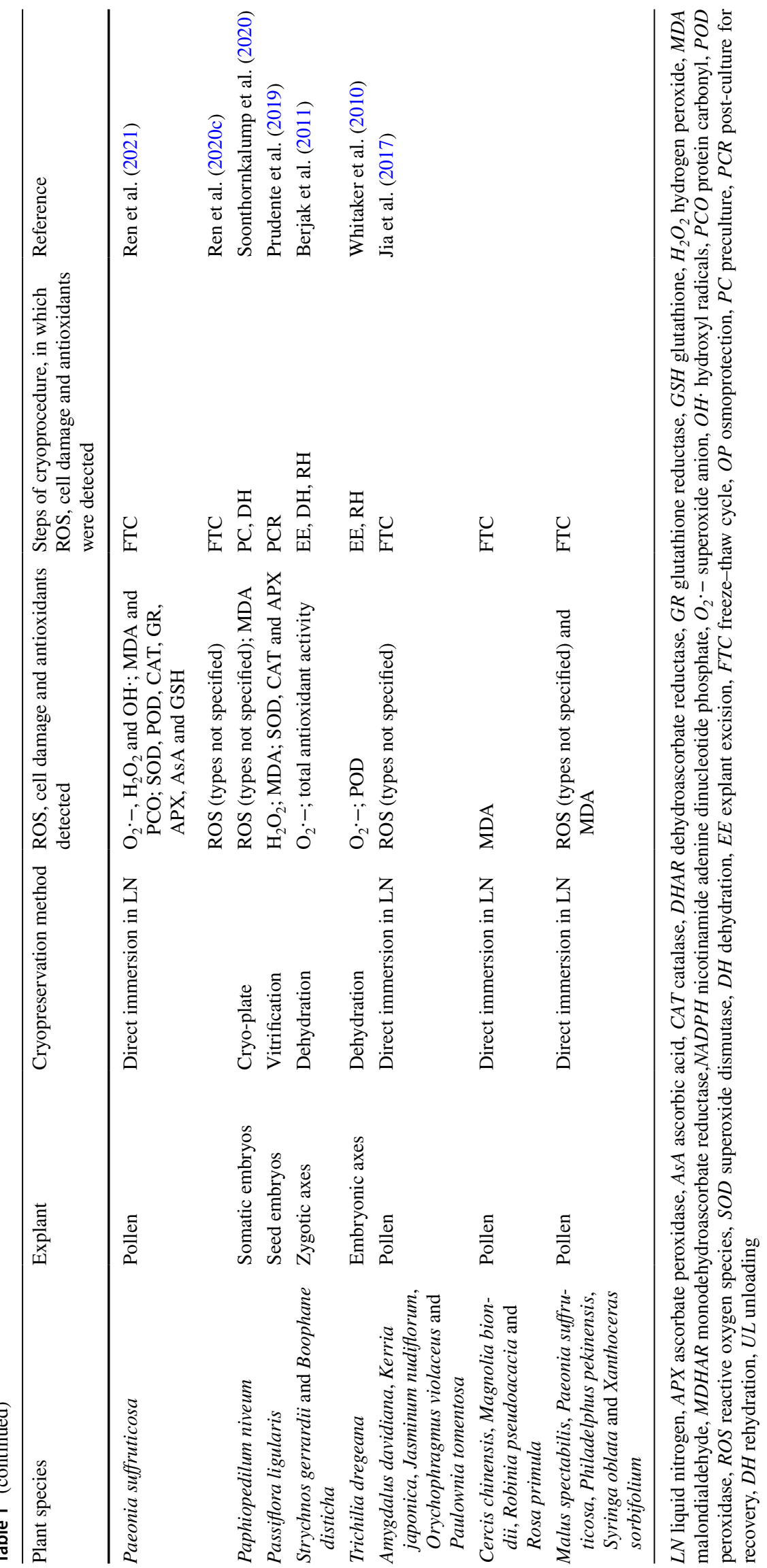


Fluorescein diacetate (FDA) staining is generally used as a marker for apoptosis-like events (Burbridge et al. 2006). Ren et al. (2013) found that the 72-h Arabidopsis seedlings completely failed to recover following cryopreservation, compared with $97 \%$ survivals in the 48 -h seedlings. The 72-h seedlings showed negative responses to FDA staining during the whole cryopreservation procedure. The defender against apoptotic death 1 ( $D A D 1)$, which encodes for the protein involved in suppression of apoptosis (Gallois et al. 1997), was found to be upregulated in the 48-h seedlings, while its expression levels maintained unchanged in the 72-h ones after dehydration (Ren et al. 2013). These results supported that apoptosis-like events were induced in the 72-h Arabidopsis seedlings during cryopreservation.

In cryopreservation of Agapanthus praecox embryogenic callus (EC), Zhang et al. (2015) found that the burst outbreak of ROS induced the occurrence of PCD. Further analysis of PCD showed that some EC cells exhibited autophagy and apoptosis-like events, and a few cells underwent necrosis during cryopreservation. Autophagy appeared at the dehydration and unloading steps, and apoptosis-like events occurred through the cryopreservation procedure. Exogenous applications of PCD modulators like caspase inhibitor and cinnamtannin B-1 significantly improved cell viability following cryopreservation (Zhang et al. 2015).

In addition, ROS-triggered PCD has also been reported in cryopreservations of pollen of Paeonia lactiflora (Ren et al. 2020b), and Paeonia suffruticosa (Ren et al. 2020c), and Agapanthus praecox embryogenic callus (Chen et al. 2021a, b). ROS-induced PCD is illustrated in Fig. 1F.

\section{Adaptive enzymatic and non-enzymatic responses of antioxidant system}

For enzymatic antioxidants, dehydration and freezing in $\mathrm{LN}$ were reported to reduce GR activity and aggravate cell membrane lipid peroxidation in zygotic embryos of Zea mays (Wen et al. 2010) and Livistona chinensis (Wen et al. 2012). Manipulations of pretreatments enhanced activities of antioxidants, especially GR, and partly increased tolerance to dehydration and freezing in LN of Olea europaea somatic embryos, resulting in increased survivals following cryopreservation (Lynch et al. 2011). Using droplet-vitrification cryopreservation of Lomandra sonderi shoot tips, Funnekotter et al. (2016) found that SOD activity was positively correlated to the recovery following cryopreservation, among the other three antioxidant enzymes CAT, GR and GPX.

In vitrification cryopreservation of Dendrobium sonia28 protocorm-like bodies (PLBs), Poobathy et al. (2013) reported that drastic increases in CAT activities were produced following the treatments of preculture, thawing and unloading, and in the initial stage of shoot regrowth following cryopreservation. In the study of droplet-vitrification for cryopreservation of Brassidium PLBs, Rahmah et al. (2015) found that the activity of APX and CAT reached the highest level in dehydration and freezing in LN. SOD activities maintained an overall increase in different steps of the cryopreservation, and reached the highest level in the late shoot regrowth stage (Poobathy et al. 2013). Huang et al. (2018) showed that the preculture treatment stimulated $\mathrm{O}_{2} \cdot-$ generation and activated the antioxidative response system in the apical meristems of germinated embryos. Treatment of osmoprotection motivated the activity of CAT and APX. In the study on vitrification cryopreservation of Dendrobium Sabin Blue PLBs, Antony et al. (2019) found that the lowest activity of CAT was obtained in the explant after exposure to the PVS2 dehydration; the lowest activity of POX enzyme following the dehydration and post-culture for shoot regrowth; and the lowest activity of APX in the thaw and unloading steps. These changes in antioxidant enzymes resulted in the low level of shoot regrowth in the explant following cryopreservation (Antony et al. 2019). In a V cryo-plate cryopreservation for Passifora suberosa shoot tips, Vianna et al. (2019) reported that the highest SOD activity was detected in the preculture step, and continuously decreased during the cryopreservation procedure. Significantly higher activities of CAT and APX were obtained after the osmoprotection treatment. CAT activity gradually decreased after osmoprotection, whereas the APX activity decreased after 10 days of post-culture. All these results indicated that the elevated activities of enzymatic antioxidants enhanced cell resistance/tolerance to cryoinjury, and control of oxidative damage via ROS homeostasis can lead to the high recovery in cryopreservation.

For non-enzymatic antioxidants, Chen et al. (2015) found that the AsA content of 48-h Arabidopsis seedlings was significantly higher than in 72-h ones from the dehydration step to post-culture for recovery. Exogenous application of AsA or $\mathrm{SK}_{3}$-type dehydrin protein to PVS2 significantly elevated the content of endogenous AsA in the dehydration step, and increased the regrowth levels of Arabidopsis seedlings after cryopreservation (Ren et al. 2015; Zhang et al. 2021a). Significantly higher contents of AsA and GSH were induced in A. praecox EC following treatments of unloading and rewarming (Zhang et al. 2015). Chen et al. (2016) found that adding exogenous GSH to PVS2 increased endogenous AsA and GSH contents after dehydration step and improved cell viability following cryopreservation. Improved viability of cryopreserved pollen of Paeonia suffruticosa was attributed to sufficient maintenance of the internal balance of oxidative metabolism by SOD, AsA and GSH (Ren et al. 2021).

A recent study clearly demonstrated that the activities of antioxidants were closely related to success of cryopreservation (Ren et al. 2021). In this study, pollen viability following cryopreservation differed among three $P$. sufruticosa cultivars: one decreased, one was stable and one increased. 
Contents of ROS, MDA and protein carbonyl (PCO) were significantly lower in the cultivar with increased viability than in the other two cultivars, while SOD activity was higher in the former than in the latter two. SOD activity was negatively correlated with the MDA and POD contents, and positively correlated with pollen viability following cryopreservation. AsA was lower, while GSH was higher, in the cultivar with increased viability than in the other two cultivars. AsA significantly increased, while GSH significantly decreased, the MDA and PCO contents. The membrane lipid oxidation and protein oxidative damage caused by ROS were responsible for the decrease in pollen viability after cryopreservation. SOD, AsA and GSH effectively maintained the internal balance of oxidative metabolism and reduced the levels of oxidative damage, thus improving pollen viability (Ren et al. 2021).

Some examples are presented in Table 1 and adaptive responses of antioxidant system induced in plant cryopreservation are illustrated in Fig. 1G.

\section{Expressions of oxidative stress-related genes and proteins in plant cryopreservation}

Over the past decade, efforts have been invested to study expressions of oxidative stress-related genes and proteins in plant cryopreservation. Some examples are presented in Table 2, and alleviation of ROS-induced oxidative stress by expressions of oxidative stress-related genes and proteins in plant cryopreservation is illustrated in Fig. 1G.

Huang et al. (2018) reported expressions of antioxidant enzyme genes $C u / Z n S O D, C A T 1, A P X 7, G R 2, G R 3$, MDHARl and DHARl in Oryza sativa zygotic embryos in vitrification cryopreservation. The authors suggested that these genes might serve as potential indicators of oxidative stress-induced genes in cryopreservation. Zhang et al. (2015) found that expressions of genes, particularly SOD and BAG, were positively related with cell viability of $A g a-$ panthus praecox EC following cryopreservation. Using high-throughput omics technology to screen two dehydrins of A. praecox EC subjected to cryopreservation, Yang et al. (2019) reported that their expression levels were specifically upregulated at the transcription and protein levels. Working on A. praecox EC, Chen et al. (2016) reported that inclusion of $0.08 \mathrm{mM}$ GSH in PVS2 markedly increased recovery of cryopreserved EC and enhanced expressions of stressresponsive genes, including $P O D, A P X, M D H A R$ and $G P X$ in the treated samples during cryopreservation procedures. Gene expression patterns provided molecular mechanisms that the application of GSH to PVS2 solution effectively improved recovery of $A$. praecox $\mathrm{EC}$.

Volk et al. (2011) used the Arabidopsis genome chip to analyze the differential expression genes of shoot tips during cryopreservation and found that dehydration-related genes were specifically upregulated after vitrification solution treatment. Application of $1 \mathrm{mM}$ AsA in PVS2 significantly increased recovery in 60-h Arabidopsis seedlings following cryopreservation (Ren et al. 2014). DREBs/CBFs assisted establishments of tolerance cryoinjury, and calcium-binding protein, OXI1, WRKY and MYB family members served as key factors in ROS signal transduction and activated the ROS-producing and -scavenging networks. Increased expressions of these genes contributed to improvements of recovery of the 60-h seedlings following cryopreservation (Ren et al. 2015). Further studies by Chen et al. (2015) and Zhang et al. (2021a) both found that upregulations of $\mathrm{Cu} / \mathrm{Zn}$ $S O D, A P X$ and $C A T$ increased tolerance to oxidative stress and improved the recovery of Arabidopsis seedlings after cryopreservation.

PVS2 and plant vitrification solution 3 (PVS3) are the most frequently used plant vitrification solutions in plant cryopreservation. Gross et al. (2017) found that expression levels of 180 transcripts differed in Arabidopsis shoot tips following exposures to PVS2 and PVS3. The transcripts induced by the treatment of PVS2 dehydration and freezing in LN induced oxidative responses, whereas the treatment of PVS3 dehydration and freezing in LN invoked more metabolic responses. These results provided molecular insights into varying levels of post-cryopreservation recoveries produced by PVS2 and PVS3 dehydration.

In the study of the translation level following treatments of sucrose or cold preculture of Solanum tuberosum and $S$. commersonii shoot tips, Folgado et al. (2014) found that the oxidative homeostasis-related proteins were associated with the improved tolerance to cryopreservation. In the study of cryopreservation of Dendrobium nobile PLBs, Di et al. (2018) found that protein synthesis, processing and degradation might be the main strategies to re-establish cell balance in the PLBs following cryopreservation. The production of ROS and the decline in energy production, signaling transduction, and membrane transport during LN exposure might be responsible for the viability loss. Studying microRNA (miRNA)-based post-transcriptional regulations in 48-h and 72-h Arabidopsis seedlings subjected to cryopreservation, Ekinci et al. (2021) demonstrated that the alteration of expression levels of cold-induced genes related-miRNAs played a key role in successful cryopreservation.

\section{Exogenous applications of antioxidants to alleviate oxidative stress for improving plant cryopreservation}

A number of studies have been conducted over the past decade on exogenous applications of enzymatic and non-enzymatic antioxidants to alleviate oxidative stress for improving 


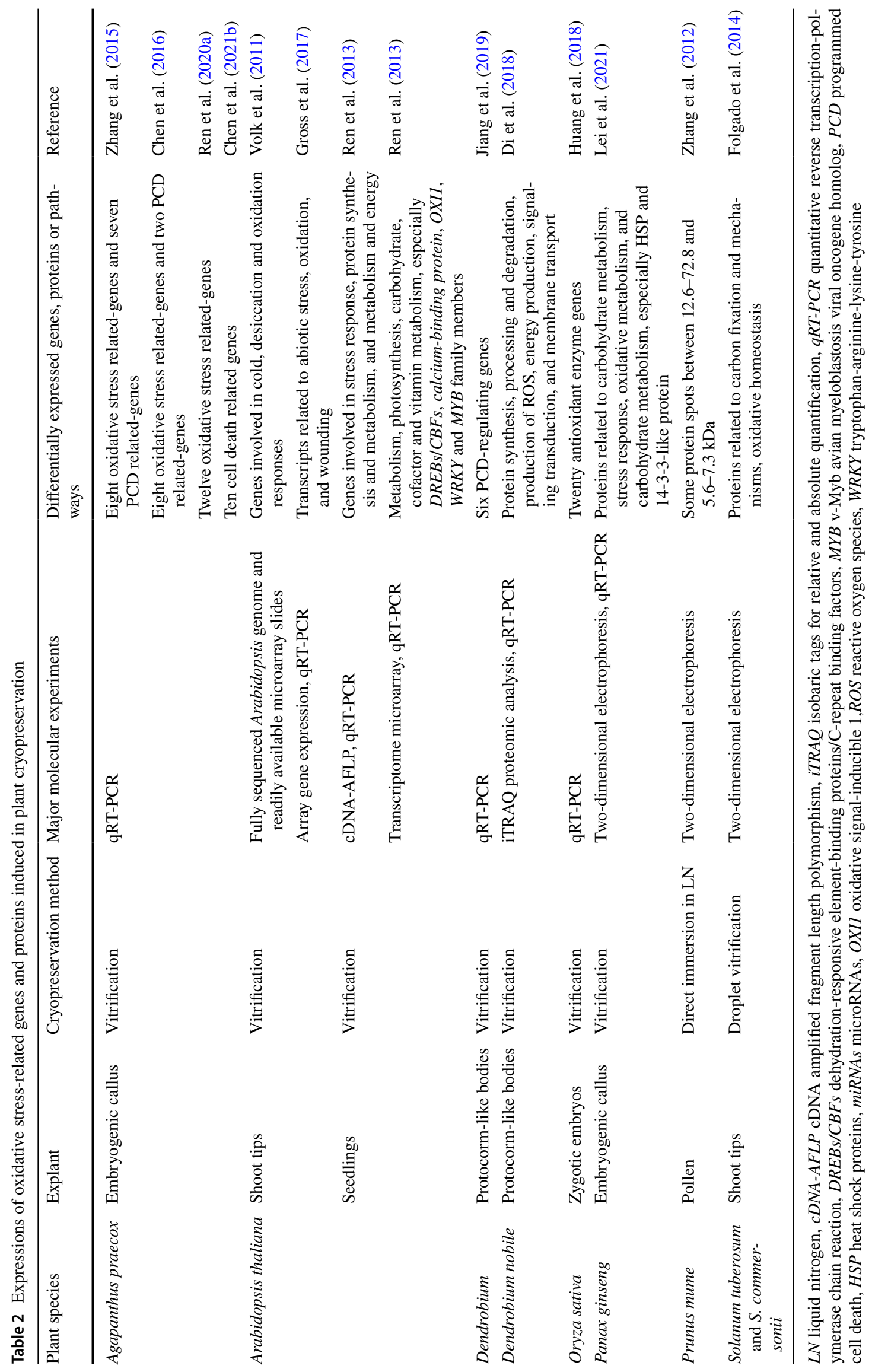




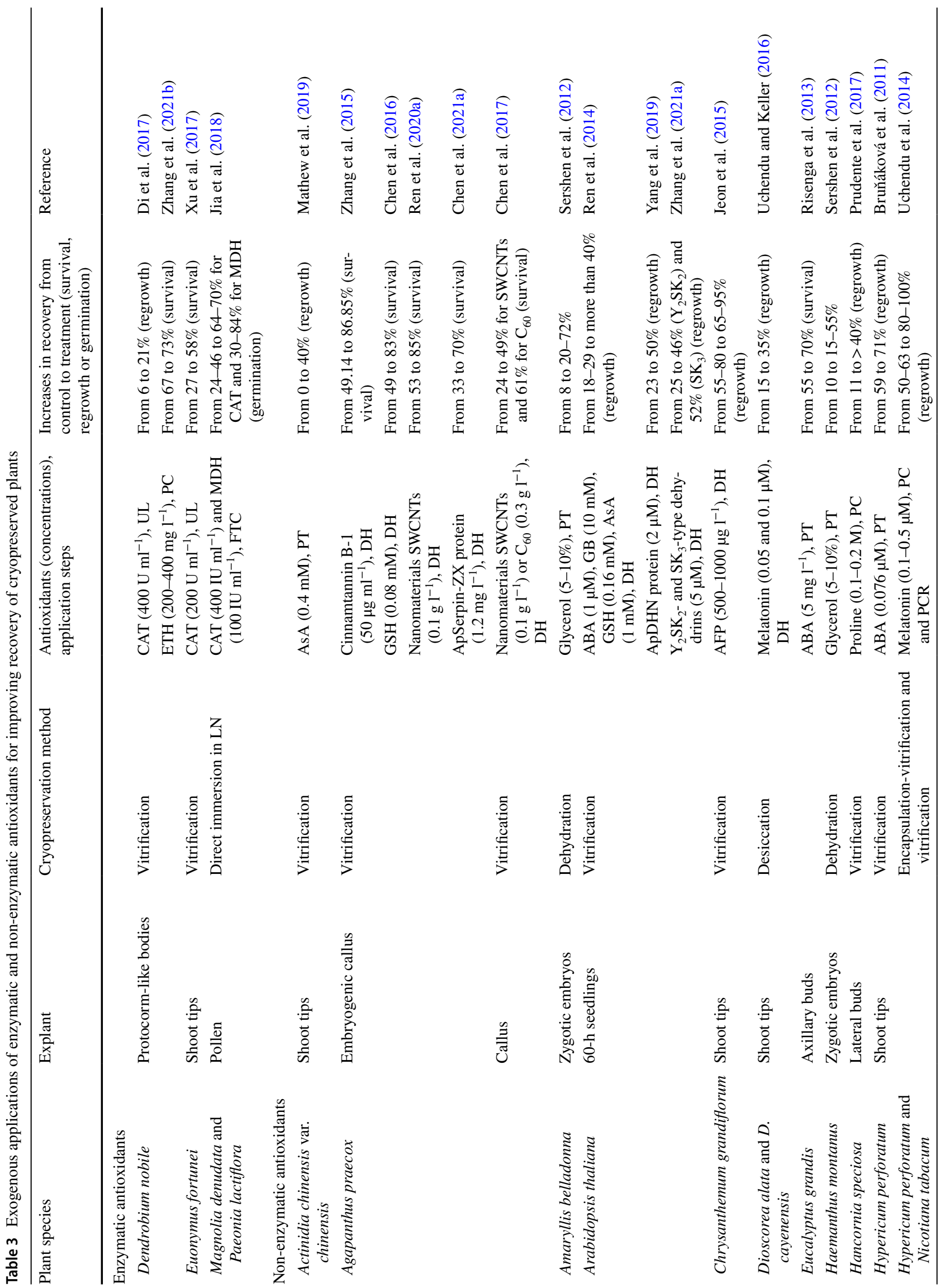




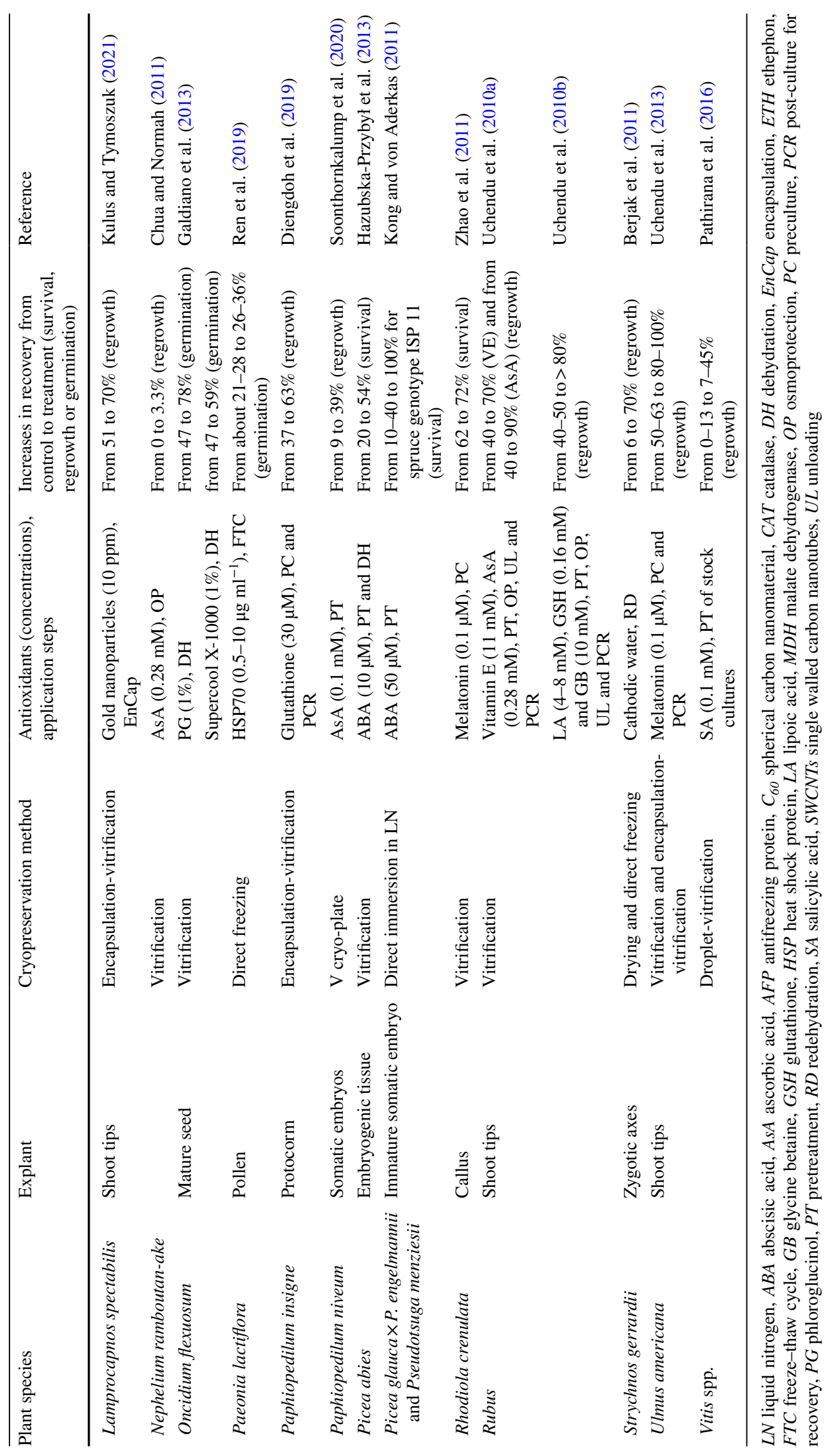


plant cryopreservation. Some examples are presented in Table 3. Improvement of recovery of cryopreserved plants by exogenous applications of the antioxidants is illustrated in Fig. 1D, G.

\section{Enzymatic antioxidants}

Testing effects of application of CAT or PDH into osmoprotection solution, PVS2 and unloading solution on vitrification cryopreservation of Dendrobium nobile PLBs, Di et al. (2017) found that adding of $400 \mathrm{IU} \mathrm{ml}^{-1}$ CAT to the unloading solution produced about $50 \%$ of survival and $21 \%$ of shoot regrowth in cryopreserved PLBs, which were significantly higher than $17 \%$ and $6 \%$ produced in the control. Another study from the same group found that only adding of $400 \mathrm{IU} \mathrm{ml}^{-1} \mathrm{CAT}$ to osmoprotection solution significantly improved survival of Euonynus fortunei shoot tips (Xu et al. 2017). Jia et al. (2018) found that inclusion of $400 \mathrm{IU} \mathrm{ml}^{-1}$ CAT in the germination solution produced much higher pollen germination rates of cryopreserved pollen than the control in Magnolia denudata and Paeonia lactifora. The addition of malate dehydrogenase (MDH) in the germination solution was also found to improve pollen germination following cryopreservation, but the optimal concentrations varied with plant species: $100 \mathrm{IU} \mathrm{ml}^{-1}$ for Magnolia denudata and $200 \mathrm{IU} \mathrm{ml}^{-1}$ for Paeonia lactifora (Jia et al. 2018). These results indicated that effects of the antioxidant enzymes on cryopreservation vary with types and concentrations of antioxidant enzymes, steps in which antioxidant enzymes are added, and plant species and explant types. Inclusion of CAT and 2-4-carboxyphenyl-4,4,5,5-tetramethylimidazoline-1-oxyl-3-oxide in the preculture medium was reported to significantly increase survival in Dendrobium PLBs following cryopreservation (Jiang et al. 2019).

Exogenous application of CAT significantly reduced $\mathrm{H}_{2} \mathrm{O}_{2}$ and MDA contents, increased AsA content and induced higher activity of endogenous CAT in the treated PLBs of Dendrobium nobile (Di et al. 2017). Jia et al. (2018) found that the use of MDH significantly reduced ROS and MDA levels, but increased SOD activity in cryopreserved pollen of $M$. denudata. Application of CAT significantly reduced levels of ROS and MDA, but increased activity of CAT and SOD in P. lactifora. These effects of CAT and MDH were believed to contribute to the improvement of recovery in cryopreserved explants (Di et al. 2017; Jia et al. 2018).

\section{Non-enzymatic antioxidants}

Over the past decade, there have been increasing interests in exogenous applications of melatonin and nanoparticles to improvements of plant cryopreservation. Non-enzymatic antioxidants such as AsA, ABA and GSH were also used as usual in plant cryopreservation.

\section{Melatonin}

Melatonin ( $N$-acetyl-5-methoxytryptamine) is an indolic compound, which is naturally biosynthesized in diverse plant species including annual and perennial species, and woody and herbaceous species (Nawaz et al. 2016). It has been well documented that melatonin is involved in regulations of all plant development processes and enhancements of resistance and/or tolerance of plants to abiotic and biotic stress.

Zhao et al. (2011) were the first to demonstrate that exogenous application of melatonin significantly improved survival of Rhodiola crenulata callus following vitrification cryopreservation. In this study, the callus was pretreated with $0.1 \mu \mathrm{M}$ melatonin at $25{ }^{\circ} \mathrm{C}$ in the dark for 5 days, followed by osmoprotection, exposure to PVS2 and freezing in LN. The melatonin pretreatment resulted in significantly higher survival level (72\%) than other treatments. The melatonin pretreatment was found to significantly reduce MDA levels and increase POD and CAT activities during the whole cryopreservation procedure. Uchendu et al. (2013) reported that exogenous application of melatonin improved recovery levels of cryopreserved shoot tips of American elm (Ulmus americana). In this study, adding $0.1-0.5 \mu \mathrm{M}$ melatonin into preculture and recovery medium resulted in $100 \%$ shoot regrowth in both in vitro-grown shoot tips and dormant buds following PVS2-vitrification and encapsulationvitrification. More examples of the improved recovery of cryopreserved plants by exogenous application of melatonin can be found in Table 3 .

\section{Nanoparticles}

Nanoparticles are defined as atomic or molecular aggregates, with their size smaller than $100 \mathrm{~nm}$ in at least one dimension (Preetha and Balakrishnan 2017). Applying gold nanoparticles (AuNPs) to preculture medium, alginate solution and recovery medium, Kulus and Tymoszuk (2021) reported that $10 \mathrm{ppm}$ AuNPs added into the alginate solution produced much higher recovery of Lamprocapnos spectabilis shoot tips following cryopreservation. AuNPs treatment significantly increased the activities of antioxidant enzyme in the LN-derived plantlets. Adding of AuNPs at 10-30 ppm in the preculture medium or at $30 \mathrm{ppm}$ in the alginate solution increased SOD activity. Much higher APX activities were obtained when 10-30 ppm AuNPs were added to the recovery medium, while adding $30 \mathrm{ppm}$ AuNPs in the recovery medium significantly increased CAT activity.

Chen et al. (2017) reported that application of $0.3 \mathrm{~g} \mathrm{l}^{-1}$ fullerene $\left(\mathrm{C}_{60}\right)$ as a cryoprotectant significantly improved 
survival of Agapanthus praecox callus following cryopreservation. Application of $\mathrm{C}_{60}$ significantly reduced the relative conductivity, the MDA content and ROS activity in the treated callus. This datum indicates that the use of $\mathrm{C}_{60}$ can alleviate oxidative stress-induced in cryopreservation by protecting the cell membrane from damage and preventing the membrane lipid peroxidation. In addition, single-wall carbon nanotubes (SWCNTs) were reported to improve cryopreservation of Agapanthus praecox EC (Ren et al. 2020a). SWCNTs $\left(0.1 \mathrm{~g} \mathrm{l}^{-1}\right)$ added in PVS2 entered EC, and most of the SWCNTs moved out at the unloading step. Analysis of the antioxidant system and oxidative stress-related gene expression found that the AsA-GSH and GPX cycle were responsible for scavenging $\mathrm{H}_{2} \mathrm{O}_{2}$ produced in the control, but the CAT cycle was essential for scavenging $\mathrm{H}_{2} \mathrm{O}_{2}$ produced in the SWCNTstreated EC, thus reducing levels of $\mathrm{H}_{2} \mathrm{O}_{2}$ and MDA. Adding of SWCNTs in PVS2 increased the antioxidant levels during dehydration, thus enhancing the resistance of the SWCNTs-treated EC to oxidative stress and improving recovery of the SWCNT-treated EC.

\section{Abscisic acid (ABA)}

ABA has been well demonstrated to increase the tolerance and/or resistance of plants to abiotic stress including freezing (Sah et al. 2016). Kong and Aderkas (2011) described a novel method for efficient cryopreservation of somatic embryogenic tissues (SETs) of interior spruce (Picea glauca $\times$ engelmannii) and Douglas-fir (Pseudotsuga menziesii subsp. menziesii). Pretreatment of SETs with $50 \mu \mathrm{M}$ $\mathrm{ABA}$ at $5{ }^{\circ} \mathrm{C}$ for $4-8$ weeks produced the highest rate of survival and all survivors retained their embryogenic ability to regenerate whole plantlets in cryopreserved SETs.

Hazubska-Przybył et al. (2013) found that adding $10 \mu \mathrm{M}$ ABA to the preculture medium improved recovery and normal plantlet regeneration in the cryopreserved SETs of Norway spruce (Picea abies). Assessments of genetic stability by simple sequence repeat (SSR) did not find any polymorphic bands in the plantlets regenerated from ABA-assisted cryopreservation. These results indicate that $\mathrm{ABA}$ can be considered safe for use in plant cryopreservation in terms of genetic stability of cryostored plants. More examples of the improved recovery of cryopreserved plants by exogenous application of ABA can be found in Table 3.

It is worth noting that Edesi et al. (2020) reported that preculture of the explant with $2-4 \mathrm{mg} \mathrm{l}^{-1} \mathrm{ABA}$ at room temperature significantly decreased shoot regrowth in cryopreserved buds of Rubus humulifolius. There existed a synergistic effect of cold and ABA treatment in many plant species (Vandenbussche and Proft 1998; Chang and Reed 2001).
Therefore, ABA-preculture at room temperature failed to produce positive effects or even exerted negative effects on cryopreservation, as reported by Edesi et al. (2020).

\section{Ascorbic acid (AsA)}

AsA (vitamin C) is the most effective water-soluble antioxidant in plants and plays an important role in protecting plants against oxidative stress (Smirnoff 2000; Gill and Tuteja 2010). In the study of V cryo-plate cryopreservation of Paphiopedilum niveum SEs, adding $0.1 \mathrm{mM}$ AsA into the preconditioning medium 1 day before the 1st preculture produced much higher recovery $(39 \%)$ than that $(8.5 \%)$ of the control (Soonthornkalump et al. 2020). AsA treatments considerably reduced ROS and MDA levels in the cryopreservation steps including 1 st preculture, 2nd preculture, osmoprotection and dehydration. More examples of the improved recovery of cryopreserved plants by exogenous application of AsA are presented in Table 3.

More recently, Khor et al. (2020) reported that the inclusion of AsA (50-150 $\mathrm{mg} \mathrm{l}^{-1}$ ) in the medium of four steps, including preculture, osmoprotection, PVS2 dehydration and post-culture, reduced the shoot regrowth percentage of cryopreserved Aranda broga PLBs. Similar results were also obtained in cryopreserved Rubus shoot tips (Uchendu et al. 2010a). High concentrations of the antioxidant disturb the redox balance and result in cellular disfunction (Bouayed and Bohn 2010). Application of AsA (2 and $8 \mathrm{mM}$ ) increased ROS contents and inhibited growth of Arabidopsis seedlings (Qian et al. 2014). These results indicated that AsA might also work as a stress factor. Therefore, beneficial effects of antioxidants including AsA on cryopreservation are dose- and plant species-specific.

\section{Glutathione (GSH)}

GSH is one of the most abundant low molecular weight thiols, which is naturally biosynthesized in plants. Uchendu et al. (2010b) reported that exogenous application of GSH exerted positive effects on recovery of cryopreserved shoot tips of Rubus. Optimal GSH concentrations for the best results of cryopreservation varied with different steps in which GHS was added. Diengdoh et al. (2019) reported that adding of GSH in the preculture and recovery medium promoted recovery of Paphiopedilum insigne protocorms in vitrification and encapsulation-vitrification cryopreservation. In vitrification cryopreservation, $10-40 \mu \mathrm{M}$ GSH enhanced shoot regrowth, with the best results obtained at $20 \mu \mathrm{M} \mathrm{GSH}$; in encapsulation-vitrification, $10-50 \mu \mathrm{M}$ GSH enhanced shoot regrowth, with the highest shoot regrowth obtained at $30 \mu \mathrm{M} \mathrm{GSH}$.

Inclusion of $8 \mu \mathrm{M} \mathrm{GSH}$ in the cryoprotectant solution significantly improved survival of Agapanthus praecox 
EC (Chen et al. 2016). The application of GSH was found to reduce $\mathrm{OH} \cdot$ and $\mathrm{O}_{2} \cdot-$ production, as well as $\mathrm{H}_{2} \mathrm{O}_{2}$ and MDA contents, while increasing endogenous AsA and GSH contents in PVS2-dehydrated EC. GSH-treatment was also found to promote expression of oxidative stress-responsive genes, including POD, APX, MDHAR and GPX during cryopreservation processes, and enhance the expression of $D A D 1$, a defender against apoptotic cell death, while suppressing cell death-related protease SBT. All these changes contributed to improvements of cryopreservation of A. prae$\operatorname{cox} \mathrm{EC}$.

\section{Others}

Several other non-enzymatic antioxidants were reported to improve cryopreservation (Table 3), such as lipoic acid (LA), vitamin E and glycine betaine (GB) for Rubus shoot tips (Uchendu et al. 2010b), cathodic water for Strychnos gerrardii zygotic embryonic axes (Berjak et al. 2011), glycerol for zygotic embryos of Amaryllis belladonna and Haemanthus montanus (Sershen et al. 2012), phloroglucinol (PG) for Oncidium flexuosum seeds (Galdiano et al. 2013) and Paphiopedilum insigne protocorms (Diengdoh et al. 2019), salicylic acid for Vitis buds (Pathirana et al. 2016), Supercool X-1000 ${ }^{\mathrm{R}}$ for Oncidium flexuosum seeds (Galdiano et al. 2013), antifreeze protein (AFP) for Chrysanthemum grandifflorum shoot tips (Jeon et al. 2015), proline for Hancornia speciosa buds (Prudente et al. 2017), ApSerpin-ZX protein for Agapanthus praecox embryogenic callus (Chen et al. 2021a), heat shock protein (HSP) for Paeonia lactifora pollen (Ren et al. 2019), and the LEA family recombinant dehydrin (DHN) proteins for Arabidopsis thaliana seedlings (Zhang et al. 2021a).

\section{Conclusion and perspectives}

A number of the studies conducted in the past decade have proven that ROS unavoidably generated in the cryopreservation process and was responsible for the low success or even total failure of plant cryopreservation. ROS generation was identified to be the trigger for PCD. Adaptive responses of the antioxidant system and expressions of the oxidative stress-associated genes and proteins helped the plant to establish resistance and/or tolerance to the oxidative stress induced during cryopreservation. Applications of enzymatic and non-enzymatic antioxidants considerably improved recovery of various explants in different cryopreservation procedures and thus provided alternative strategies for efficient cryopreservation of plants. All these results are helpful for further developments and wider applications of plant cryobiotechnology.
Oxidative stress has been identified to be a major constraint for further developments of plant cryopreservation. To alleviate oxidative stress for improving recovery of cryopreserved plants, further studies should be strengthened in the following aspects: (1) to better understand how the explants respond to ROS-induced oxidative stress; (2) to elucidate the mechanism as to how the explants establish resistance and/or tolerance to ROS-induced oxidative stress; and (3) to apply both enzymatic and non-enzymatic antioxidants for improving cryopreservation of plants, particularly endangered, endemic and tropical species, which are still recalcitrant to cryopreservation; (4) various methods for quantitative analysis and visual observations have been used on the studies of ROS generations in plant cryopreservation. Novel and advanced techniques should be considered for use in the said subject. For example, fluorescence probes for monitoring ROS generations offer a potentially powerful tool for studying the chemistry and biology of ROS with high spatial and temporal resolution (Choi et al. 2012). High-throughput omics technology can be used to identify functions of the specific genes and proteins in protecting the cells against ROS-induced oxidative stress (Yang et al. 2019). These studies are expected to develop robust cryopreservation protocols, which can be used as routine methods for setting-up cryobanks of genetic resources of diverse plant species, and facilitate wider applications of cryobiotechnology.

Author contribution statement LR: data collection and analysis, writing of original manuscript; preparation of Tables 1, 2 and 3, and manuscript revision; M-RW: data collection and analysis, preparation of Fig. 1 and manuscript revision; Q-CW: proposal of the present study, manuscript revision and financial supports.

Funding This work was partly supported by the National Natural Science Foundation of China (project number 31870686) and the National Key R\&D Program of China (project number 2019YFD1001803).

Data availability The datasets generated or analyzed during the current study are available from the corresponding author on reasonable request.

\section{Declarations}

Conflict of interest The authors declare no conflict of interest.

Open Access This article is licensed under a Creative Commons Attribution 4.0 International License, which permits use, sharing, adaptation, distribution and reproduction in any medium or format, as long as you give appropriate credit to the original author(s) and the source, provide a link to the Creative Commons licence, and indicate if changes 
were made. The images or other third party material in this article are included in the article's Creative Commons licence, unless indicated otherwise in a credit line to the material. If material is not included in the article's Creative Commons licence and your intended use is not permitted by statutory regulation or exceeds the permitted use, you will need to obtain permission directly from the copyright holder. To view a copy of this licence, visit http://creativecommons.org/licenses/by/4.0/.

\section{References}

Antony JJJ, Zakaria S, Zakaria R, Ujang JA, Othman N, Subramaniam S (2019) Biochemical analyses of Dendrobium Sabin Blue PLBs during cryopreservation by vitrification. Physiol Mol Biol Plant 25:1457-1467

Bednarek PT, Orłowska R (2020) Plant tissue culture environment as a switch-key of (epi)genetic changes. Plant Cell Tissue Organ Cult 140:245-257

Benson EE, Bremner D (2004) Oxidative stress in the frozen plant: a free radical point of view. In: Fuller BJ, Lane N, Benson EE (eds) Life in the frozen state. CRC Press, Boca Raton, pp 206-241

Berjak P, Sershen VB, Pammenter NW (2011) Cathodic amelioration of the adverse effects of oxidative stress accompanying procedures necessary for cryopreservation of embryonic axes of recalcitrant-seeded species. Seed Sci Res 21:187-203

Bettoni JC, Bonnart R, Volk GM (2021) Challenges in implementing plant shoot tip cryopreservation technologies. Plant Cell Tissue Organ Cult 144:21-34

Bharuth V, Naidoo C (2020) Responses to cryopreservation of recalcitrant seeds of Ekebergia capensis from different provenances. S Afr J Bot 132:1-14

Bi W, Saxena A, Ayyanath MM, Harpur C, Shukla MR, Saxena PK (2021) Conservation, propagation, and redistribution (CPR) of Hill's thistle: paradigm for plant species at risk. Plant Cell Tissue Organ Cult 145:75-88

Bissoyi A, Nayak B, Pramanik K, Sarangi SK (2014) Targeting cryopreservation-induced cell death: a review. Biopreservation Biobanking 12:23-34

Bouayed J, Bohn T (2010) Exogenous antioxidants-double-edged swords in cellular redox state: health beneficial effects at physiologic doses versus deleterious effects at high doses. Oxid Med Cell Longev 3:228-237

Bruňáková K, Zámečník J, Urbanová M, Čellárová E (2011) Dehydration status of ABA-treated and cold-acclimated Hypericum perforatum $\mathrm{L}$. shoot tips subjected to cryopreservation. Thermochim Acta 525:62-70

Burbridge E, Diamond M, Dix PJ, McCabe PF (2006) Use of cell morphology to evaluate the effect of a peroxidase gene on cell death induction thresholds in tobacco. Plant Sci 171:139-146

Chaitanya KV, Sundar D, Masilamani S, Ramachandra Reddy A (2002) Variation in heat stress-induced antioxidant enzyme activities among three mulberry cultivars. Plant Growth Regul 36:175-180

Chang Y, Reed BM (2001) Preculture conditions influence cold hardiness and regrowth of Pyrus cordata shoot tips after cryopreservation. HortScience 36:1329-1333

Chen GQ, Ren L, Zhang J, Reed BM, Zhang D, Shen XH (2015) Cryopreservation affects ROS-induced oxidative stress and antioxidant response in Arabidopsis seedlings. Cryobiology 70:38-47

Chen GQ, Ren L, Zhang D, Shen XH (2016) Glutathione improves survival of cryopreserved embryogenic calli of Agapanthus praecox subsp. orientalis. Acta Physiol Plant 38:250. https://doi.org/10. 1007/s11738-016-2271-y
Chen S-M, Ren L, Zhang D, Zhang Y-F, Shen X-H (2017) Carbon nanomaterials enhance survival rates of Agapanthus praecox callus after vitrification cryopreservation. CryoLetters 38:125-136

Chen G, Li R, Shen X (2021a) ApSerpin-ZX from Agapanthus praecox, is a potential cryoprotective agent to plant cryopreservation. Cryobiology 98:103-111

Chen G, Zhang D, Pan J, Yue J, Shen X (2021b) Cathepsin B-like cysteine protease ApCathB negatively regulates cryo-injury tolerance in transgenic Arabidopsis and Agapanthus praecox. Plant Sci 308:110928. https://doi.org/10.1016/j.plantsci.2021.110928

Choi W-G, Swanson SJ, Gilroy S (2012) High-resolution imaging of $\mathrm{Ca}_{2}{ }^{+}$, redox status, ROS and $\mathrm{pH}$ using GFP biosensors. Plant $\mathrm{J}$ 70:118-128

Chua SP, Normah MN (2011) Effect of preculture, PVS2 and vitamin $\mathrm{C}$ on survival of recalcitrant Nephelium ramboutanake shoot tips after cryopreservation by vitrification. CryoLetters 32:506-515

Coelho N, Gonçalves S, Romano A (2020) Endemic plant species conservation: biotechnological approaches. Plants 9:345. https://doi. org/10.3390/plants9030345

Di W, Jia M, Xu J, Li B, Liu Y (2017) Exogenous catalase and pyruvate dehydrogenase improve survival and regeneration and affect oxidative stress in cryopreserved Dendrobium nobile protocorm-like bodies. CryoLetters 38:228-238

Di W, Jiang X, Xu J, Jia M, Li B, Liu Y (2018) Stress and damage mechanisms in Dendrobium nobile Lindl. protocorm-like bodies during pre- and post-liquid nitrogen exposure in cryopreservation revealed by iTRAQ proteomic analysis. In Vitro Cell Dev Biol Plant 54:253-272

Diengdoh RV, Kumaria S, Das MC (2019) Antioxidants and improved regrowth procedure facilitated cryoconservation of Paphiopedilum insigne Wall. Ex. Lindl. - an endangered slipper orchid. Cryobiology 87:60-67

Edesi J, Tolonen J, Ruotsalainen AL, Aspi J, Häggman H (2020) Cryopreservation enables long-term conservation of critically endangered species Rubus humulifolius. Biodivers Conserv 29:303-314

Ekinci MH, Kayıhan DS, Kayıhan C, Çiftçi YÖ (2021) The role of microRNAs in recovery rates of Arabidopsis thaliana after short term cryo-storage. Plant Cell Tissue Organ Cult 144:281-293

Folgado R, Sergeant K, Renaut J, Swennen R, Hausman J-F, Panis B (2014) Changes in sugar content and proteome of potato in response to cold and dehydration stress and their implications for cryopreservation. J Proteomics 98:99-111

Funnekotter B, Sortey A, Bunn E, Turner S, Mancera R (2016) Influence of abiotic stress preconditioning on antioxidant enzymes in shoot tips of Lomandra sonderi (Asparagaceae) prior to cryostorage. Aust J Bot 64:260-268

Funnekotter B, Colville L, Kaczmarczyk A, Turner SR, Bunn E, Mancera RL (2017) Monitoring of oxidative status in three native Australian species during cold acclimation and cryopreservation. Plant Cell Rep 36:1903-1916

Galdiano RF Jr, de Macedo Lemos EG, Vendrame WA (2013) Cryopreservation, early seedling development, and genetic stability of Oncidium flexuosum Sims. Plant Cell Tissue Organ Cult 114:139-148

Gallois P, Makishima T, Hecht V, Despres B, Laudie M, Nishimoto T, Cooke R (1997) An Arabidopsis thaliana cDNA complementing a hamster apoptosis suppressor mutant. Plant J 11:1325-1331

Gill SS, Tuteja N (2010) Reactive oxygen species and antioxidant machinery in abiotic stress tolerance in crop plants. Plant Physiol Biochem 48:909-930

Gross BL, Henk AD, Bonnart R, Volk GM (2017) Changes in transcript expression patterns as a result of cryoprotectant treatment and liquid nitrogen exposure in Arabidopsis shoot tips. Plant Cell Rep 36:459-470 
Halder T, Upadhyaya G, Basak C, Das A, Chakraborty C, Ray S (2018) Dehydrins impart protection against oxidative stress in transgenic tobacco plants. Front Plant Sci 9:136. https://doi.org/10.3389/ fpls.2018.00136

Halliwell B (2006) Reactive species and antioxidants. Plant Physiol $141: 312-322$

Harding K, Johnston JW, Benson EE (2009) Exploring the physiological basis of cryopreservation success and failure in clonally propagated in vitro crop plant germplasm. Agric Food Sci 18:103-116

Hazubska-Przybył T, Chmielarz P, Michalak M, Dering M, Bojarczuk K (2013) Survival and genetic stability of Picea abies embryogenic cultures after cryopreservation using a pregrowth-dehydration method. Plant Cell Tissue Organ Cult 113:303-313

Huang B, Zhang JM, Chen XL, Xin X, Yin GK, He JJ, Lu XX, Zhou YC (2018) Oxidative damage and antioxidantive indicators in 48 $\mathrm{h}$ germinated rice embryos during the vitrification-cryopreservation procedure. Plant Cell Rep 37:1325-1342

Jenderek MM, Reed BM (2017) Cryopreserved storage of clonal germplasm in the USDA National Plant Germplasm System. In Vitro Cell Dev Biol Plant 53:299-308

Jeon SM, Naing AH, Park KI, Kim CK (2015) The effect of antifreeze protein on the cryopreservation of chrysanthemums. Plant Cell Tissue Organ Cult 123:665-671

Jia MX, Di W, Liu Y, Shi Y, Xie Y (2016) ROS-induced oxidative stress in nobile-type Dendrobium protocorm-like bodies (PLBS) during vitrification. CryoLetters 37:253-263

Jia MX, Shi Y, Di W, Jiang XR, Xu J, Liu Y (2017) ROS-induced oxidative stress is closely related to pollen deterioration following cryopreservation. In Vitro Cell Dev Biol Plant 53:433-439

Jia MX, Jiang RJ, Xu J, Di W, Shi Y, Liu Y (2018) CAT and MDH improve the germination and alleviate the oxidative stress of cryopreserved Paeonia and Magnolia pollen. Acta Physiol Plant 40:37. https://doi.org/10.1007/s11738-018-2612-0

Jiang X, Ren R, Di W, Jia M, Li Z, Liu Y, Gao R (2019) Hydrogen peroxide and nitric oxide are involved in programmed cell death induced by cryopreservation in Dendrobium protocormlike bodies. Plant Cell Tissue Organ Cult 137:553-563

Kaczmarczyk A, Funnekotter B, Menon A, Phang PY, Al-Hanbali A, Bunn E, Mancera RL (2012) Current issues in plant cryopreservation. In: Katkov II (ed) Current frontiers in cryobiology. InTech, Croatia, pp 417-438

Khor SP, Yeow LC, Poobathy R, Zakaria R, Chew BL, Subramaniam S (2020) Droplet-vitrification of Aranda Broga Blue orchid: role of ascorbic acid on the antioxidant system and genetic fidelity assessments via RAPD and SCoT markers. Biotechnol Rep. https://doi.org/10.1016/j.btre.2020.e00448

Kong L, von Aderkas P (2011) A novel method of cryopreservation without a cryoprotectant for immature somatic embryos of conifer. Plant Cell Tissue Organ Cult 106:115-125

Kulus D, Tymoszuk A (2021) Gold nanoparticles affect the cryopreservation efficiency of in vitro-derived shoot tips of bleeding heart. Plant Cell Tissue Organ Cult. https://doi.org/10. 1007/s11240-021-02069-4

Kulus D, Zalewska M (2014) Cryopreservation as a tool used in long-term storage of ornamental species-a review. Sci Hortic 168:88-107

Lei X, Wang Q, Yang H, Qi Y, Hao X, Wang Y (2021) Vitrification and proteomic analysis of embryogenic callus of Panax ginseng CA Meyer. In Vitro Cell Dev Biol Plant 57:118-127

Lynch PT, Siddika A, Johnston JW, Trigwell SM, Mehra A, Benelli C, Lambardi M, Benson EE (2011) Effects of osmotic pretreatments on oxidative stress, antioxidant profiles and cryopreservation of olive somatic embryos. Plant Sci 181:47-56

Mathew L, Burritt DJ, McLachlan A, Pathirana R (2019) Combined pre-treatments enhance antioxidant metabolism and improve survival of cryopreserved kiwifruit shoot tips. Plant Cell Tissue Organ Cult 138:193-205

Mittler R (2002) Oxidative stress, antioxidants and stress tolerance. Trend Plant Sci 7:405-410

Mittler R (2017) ROS are good. Trend Plant Sci 22:11-19

Nawaz MA, Huang Y, Bie Z, Ahmed W, Reiter RJ, Niu M, Hameed S (2016) Melatonin: current status and future perspectives in plant science. Front Plant Sci 6:1230. https://doi.org/10.3389/ fpls.2015.01230

Noctor G, Foyer CH (1998) Ascorbate and glutathione: keeping active oxygen under control. Ann Rev Plant Biol 49:249-279

Normah MN, Sulonga N, Reed BM (2019) Cryopreservation of shoot tips of recalcitrant and tropical species: advances and strategies. Cryobiology 87:1-14

Pastori G, Mullineaux P, Foyer CH (2000) Post transcriptional regulation prevents accumulation of glutathione reductase protein and activity in the bundle sheath cells of maize. Implication on the sensitivity of maize to temperatures. Plant Physiol 122:667-675

Pathirana R, McLachlan A, Hedderley D, Panis B, Carimi F (2016) Pre-treatment with salicylic acid improves plant regeneration after cryopreservation of grapevine (Vitis spp.) by droplet vitrification. Acta Physiol Plant 38:1-11

Poobathy R, Sinniah UR, Xavier R, Subramaniam S (2013) Catalase and superoxide dismutase activities and the total protein content of protocorm-like bodies of Dendrobium Sonia-28 subjected to vitrification. Appl Biochem Biotechnol 170:1066-1079

Preetha PS, Balakrishnan N (2017) A review of nano fertilizers and their use and functions in soil. Int J Curr Microbiol Appl Sci 6:3117-3133

Prudente DO, Paiva R, Nery FC, Paiva PDO, Alves JD, Máximo WPF, Silva LC (2017) Compatible solutes improve regrowth, ameliorate enzymatic antioxidant systems, and reduce lipid peroxidation of cryopreserved Hancornia speciosa Gomes lateral buds. In Vitro Cell Dev Biol Plant 53:352-362

Prudente DO, Paiva R, Domiciano D, Souza LB, Carpentier S, Swennen R, Silva LC, Nery FC, Máximo WPF, Panis B (2019) The cryoprotectant PVS2 plays a crucial role in germinating Passiflora ligularis embryos after cryopreservation by influencing the mobilization of lipids and the antioxidant metabolism. J Plant Physiol 239:71-82

Qian HF, Peng XF, Han X, Ren J, Zhan KY, Zhu M (2014) The stress factor, exogenous ascorbic acid, affects plant growth and the antioxidant system in Arabidopsis thaliana. Russ J Plant Physiol 61:467-475

Rahmah S, Mubbarakh A, Ping S, Subramaniam KS (2015) Effects of droplet-vitrification cryopreservation based on physiological and antioxidant enzyme activities of Brassidium shooting star orchid. Sci World J. https://doi.org/10.1155/2015/961793

Reape TJ, McCabe P (2008) Apoptotic-like programmed cell death in plants. New Phytol 180:13-26

Reed BM (2014) Antioxidants and cryopreservation, the new normal? Acta Hortic 1039:41-48

Ren L, Zhang D, Jiang X, Gai Y, Wang W, Reed BM, Shen X (2013) Peroxidation due to cryoprotectant step is a vital factor for cell survival in Arabidopsis cryopreservation. Plant Sci 212:37-47

Ren L, Zhang D, Shen XH, Reed RM (2014) Antioxidants and antistress compounds improve the survival of cryopreserved Arabidopsis seedlings. Acta Hortic 1039:57-62

Ren L, Zhang D, Chen G, Reed BM, Shen X, Chen H (2015) Transcriptomic profiling revealed the regulatory mechanism of Arabidopsis seedlings response to oxidative stress from cryopreservation. Plant Cell Rep 34:2161-2178

Ren R, Jiang X, Di W, Li Z, Li B, Xu J, Liu Y (2019) HSP70 improves the viability of cryopreserved Paeonia lactiflora pollen by regulating oxidative stress and apoptosis-like programmed cell death events. Plant Cell Tissue Organ Cult 139:53-64 
Ren L, Deng S, Chu Y, Zhang Y, Zhao H, Chen H, Zhang D (2020a) Single-wall carbon nanotubes improve cell survival rate and reduce oxidative injury in cryopreservation of Agapanthus praecox embryogenic callus. Plant Methods 16:130. https://doi.org/ 10.1186/s13007-020-00674-6

Ren R, Li Z, Jiang X, Liu Y (2020b) The ROS-associated programmed cell death causes the decline of pollen viability recovered from cryopreservation in Paeonia lactiflora. Plant Cell Rep 39:941-952

Ren R, Li Z, Zhou H, Zhang L, Jiang X, Liu Y (2020c) Changes in apoptosis-like programmed cell death and viability during the cryopreservation of pollen from Paeonia suffruticosa. Plant Cell Tissue Organ Cult 140:357-368

Ren R, Li Z, Zhang L, Zhou H, Jiang X, Liu Y (2021) Enzymatic and nonenzymatic antioxidant systems impact the viability of cryopreserved Paeonia suffruticosa pollen. Plant Cell Tissue Organ Cult 144:233-246

Risenga I, Watt P, Mycock D (2013) Programmed cell death and necrosis during cryopreservative drying of in vitro Eucalyptus grandis axillary buds. CryoLetters 34:583-597

Roach T, Ivanova M, Beckett RP, Minibayeva FV, Green I, Pritchard HW, Kranner I (2008) An oxidative burst of superoxide in embryonic axes of recalcitrant sweet chestnut seeds as induced by excision and desiccation. Physiol Plant 133:131-139

Sah SK, Reddy KR, Li J (2016) Abscisic acid and abiotic stress tolerance in crop plants. Front Plant Sci 7:571. https://doi.org/10. 3389/fpls.2016.00571

Salama A, Popova E, Jones MP, Shukla MR, Fisk NS, Saxena PK (2018) Cryopreservation of the critically endangered golden paintbrush (Castilleja levisecta Greenm.): from nature to cryobank to nature. In Vitro Cell Dev Biol Plant 54:69-78

Savatin DV, Gramegna G, Modesti V, Cervone F (2014) Wounding in the plant tissue: the defense of a dangerous passage. Front Plant Sci 47:5. https://doi.org/10.3389/fpls.2014.00470

Scandalios JG (1990) Response of plant antioxidant defense genes to environmental stress. Adv Gen 28:1-41

Sershen VB, Pammenter NW, Berjak P (2012) Cryo-tolerance of zygotic embryos from recalcitrant seeds in relation to oxidative stress - a case study on two amaryllid species. J Plant Physiol 169:999-1011

Skyba M, Petijová L, Košuth J, Koleva DP, Ganeva TG, KapchinaToteva VM, Čellárová E (2012) Oxidative stress and antioxidant response in Hypericum perforatum L. plants subjected to low temperature treatment. J Plant Physiol 169:955-964

Smirnoff N (2000) Ascorbic acid: metabolism and functions of a multifacetted molecule. Curr Opin Plant Biol 3:229-235

Soonthornkalump S, Yamamoto S-i, Meesawat U (2020) Adding ascorbic acid to reduce oxidative stress during cryopreservation of somatic embryos of aphiopedilum niveum (Rchb.f.) Stein, an endangered orchid species. Hortic J 89:466-472

Streczynski R, Clark H, Whelehan LM, Ang S-T, Hardstaff LK, Funnekotter B, Bunn E, Offord CA, Sommerville KD, Mancera RL (2019) Current issues in plant cryopreservation and importance for ex situ conservation of threatened Australian native species. Aust J Bot 67:1-15

Uchendu EE, Keller ERJ (2016) Melatonin-laoded alginate beads improved cryopreservation of yam (Dioscorea alata and D. cayenensis). CryoLetters 37:77-87

Uchendu EE, Leonard SW, Traber MG, Reed BM (2010a) Vitamins $\mathrm{C}$ and $\mathrm{E}$ improve regrowth and reduce lipid peroxidation of blackberry shoot tips following cryopreservation. Plant Cell Rep 29:25-35

Uchendu EE, Muminova M, Gupta S, Reed MM (2010b) Antioxidant and anti-stress compounds improve regrowth of cryopreserved Rubus shoot tips. In Vitro Cell Dev Biol Plant 46:386-393
Uchendu EE, Shukla MR, Reed BM, Saxena PK (2013) Melatonin enhances the recovery of cryopreserved shoot tips of American elm (Ulmus americana L.). J Pineal Res 55:435-442

Uchendu EE, Shukla MR, Reed BM, Saxena PK (2014) An efficient method for cryopreservation of St John's Wort and tobacco: role of melatonin. Acta Hortic 1039:233-243

Vandenbussche B, De Proft MP (1998) Cryopreservation of in vitro sugar beet shoot tips using the encapsulation-dehydration technique: influence of abscisic acid and cold acclimation. Plant Cell Rep 17:791-793

Vianna MG, Garcia RO, Mansur E, Engelmann F, Pacheco G (2019) Oxidative stress during the cryopreservation of Passiflora suberos $a$ L. shoot tips using the V-Cryo-plate technique: determination of the critical stages of the protocol. Plant Cell Tissue Organ Cult 139:369-379

Volk GM, Henk A, Basu C (2011) Gene expression in response to cryoprotectant and liquid nitrogen exposure in Arabidopsis shoot tips. Acta Hortic 908:55-66

Vollmer R, Villagaray R, Egúsquiza V, Espirilla J, García M, Torres A, Rojas E, Panta A, Barkley N, Ellis D (2016) The potato cryobank at the International Potato Center (CIP): a model for long term conservation of clonal plant genetic resources collections of the future. CryoLetters 37:318-329

Vranová E, Inzé D, Van Breusegem F (2002) Signal transduction during oxidative stress. J Exp Bot 53:1227-1236

Wang QC, Perl A (2006) Cryopreservation in floricultural crops. In: Silva JT (ed) Floricultural, ornamental and plant biotechnology: advances and topics. Global Science Books, London, pp 523-539

Wang Q-C, Valkonen JPT (2009) Cryotherapy of shoot tips: novel pathogen eradication method. Trend Plant Sci 14:119-122

Wang B, Zhang Z, Yin Z, Feng C, Wang Q-C (2012) Novel and potential application of cryopreservation to plant genetic transformation. Biotechnol Adv 30:604-612

Wang B, Wang R-R, Cui Z-H, Bi W-L, Li J-W, Li B-Q, Ozudogru EA, Volk GM, Wang Q-C (2014) Potential applications of cryogenic technologies to plant genetic improvement and pathogen eradication. Biotechnol Adv 32:583-595

Wang M-R, Lambardi M, Engelmann F, Pathirana R, Panis B, Volk GM, Wang Q-C (2021a) Advances in cryopreservation of in vitro-derived propagules: technologies and explant resources. Plant Cell Tissue Organ Cult 144:7-20

Wang M-R, Bi W, Shukla MR, Ren L, Hamborg Z, Blystad D-R, Saxena PK, Wang Q-C (2021b) Epigenetic and genetic integrity, metabolic stability, and field performance of cryopreserved plants. Plants 10:1889. https://doi.org/10.3390/plants10091889

Wawrzyniak MK, Michalak M, Chmielarz P (2020) Effect of different conditions of storage on seed viability and seedling growth of six European wild fruit woody plants. Ann for Sci 77:1-20

Wen B, Wang R, Cheng H, Song S (2010) Cytological and physiological changes in orthodox maize embryos during cryopreservation. Protoplasma 239:57-67

Wen B, Cai C, Wang R, Song S, Song J (2012) Cytological and physiological changes in recalcitrant Chinese fanpalm (Livistona chinensis) embryos during cryopreservation. Protoplasma 249:323-335

Wesley-Smith J, Walters C, Pammenter NW, Berjak P (2015) Why is intracellular ice lethal? A microscopical study showing evidence of programmed cell death in cryo-exposed embryonic axes of recalcitrant seeds of Acer saccharinum. Ann Bot 115:991-1000

Whitaker C, Beckett RP, Minibayeva FV, Kranner I (2010) Production of reactive oxygen species in excised and cryopreserved explants of Trichilia dregeana Sond. S Afr J Bot 76:112-118

Xu J, Liu Q, Jia M, Liu Y, Li B, Shi Y (2014) Generation of reactive oxygen species during cryopreservation may improve Lilium $\times$ siberia pollen viability. In Vitro Cell Dev Biol Plant 50:369-375 
Xu J, Liu Y, Li B, Wang Z, Liu Q, Shi Y (2017) Effects of catalase and malate dehydrogenase on cryopreservation of Euonymus forunei (Turcz.) Hand.-Maz. Shoot tips by vitrification. Propag Ornam Plant 17:20-28

Yang Z, Sheng J, Lv K, Ren L, Zhang D (2019) $\mathrm{Y}_{2} \mathrm{SK}_{2}$ and $\mathrm{SK}_{3}$ type dehydrins from Agapanthus praecox can improve plant stress tolerance and act as multifunctional protectants. Plant Sci 284:143-160

Zhang YL, Li BL, Wang H, Liu Y (2012) Changes in total soluble proteins and $\mathrm{Ca}^{2+}$ upon cryopreservation of Prunus mume pollen. CryoLetters 33:394-401

Zhang D, Ren L, Chen GQ, Zhang J, Reed BM, Shen XH (2015) ROSinduced oxidative stress and apoptosis-like event directly affect the cell viability of cryopreserved embryogenic callus in Agapanthus praecox. Plant Cell Rep 34:1499-1513

Zhang D, Yang T, Ren L (2021a) $\mathrm{Y}_{2} \mathrm{SK}_{2^{-}}$and $\mathrm{SK}_{3}$-type dehydrins from Agapanthus praecox act as protectants to improve plant cell viability during cryopreservation. Plant Cell Tissue Organ Cult 144:271-279
Zhang L, Ren R, Jiang X, Zhou H, Liu Y (2021b) Exogenous ethylene increases the viability of cryopreserved Dendrobium protocormlike bodies by regulating the hydrogen peroxide and its mediated oxidative stress. Plant Cell Tissue Organ Cult 145:19-27

Zhao Y, Qi LW, Wang WM, Saxena PK, Liu CZ (2011) Melatonin improves the survival of cryopreserved callus of Rhodiola crenulata. J Pineal Res 50:83-88

Zhao L, Wang M-R, Li J-W, Volk GM, Wang Q-C (2019) Cryobiotechnology: a double-edged sword for plant obligate pathogens. Plant Dis 103:1058-1067

Publisher's Note Springer Nature remains neutral with regard to jurisdictional claims in published maps and institutional affiliations. 